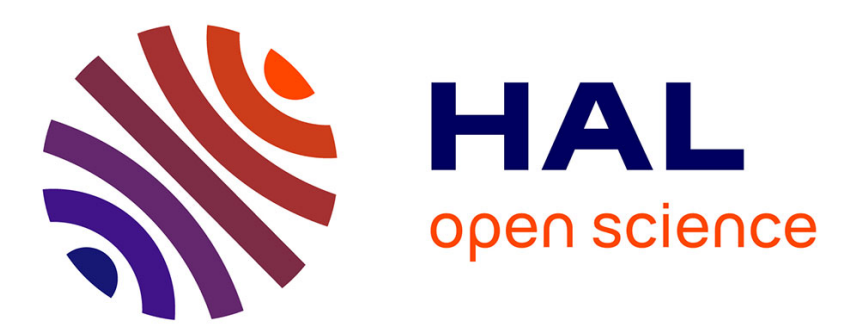

\title{
Alternative strawberry production using solarization, metham sodium and beneficial soil microbes as plant protection methods
}

A. Camprubí, V. Estaún, M.A. El Bakali, F. Garcia-Figueres, Coralie Calvet

\section{- To cite this version:}

A. Camprubí, V. Estaún, M.A. El Bakali, F. Garcia-Figueres, Coralie Calvet. Alternative strawberry production using solarization, metham sodium and beneficial soil microbes as plant protection methods. Agronomy for Sustainable Development, 2007, 27 (3), pp.179-184. hal-00886361

\section{HAL Id: hal-00886361 https://hal.science/hal-00886361}

Submitted on 1 Jan 2007

HAL is a multi-disciplinary open access archive for the deposit and dissemination of scientific research documents, whether they are published or not. The documents may come from teaching and research institutions in France or abroad, or from public or private research centers.
L'archive ouverte pluridisciplinaire $\mathbf{H A L}$, est destinée au dépôt et à la diffusion de documents scientifiques de niveau recherche, publiés ou non, émanant des établissements d'enseignement et de recherche français ou étrangers, des laboratoires publics ou privés. 


\title{
Alternative strawberry production using solarization, metham sodium and beneficial soil microbes as plant protection methods
}

\author{
A. CAMPrubía* ${ }^{*}$, V. Estaún ${ }^{\mathrm{a}}$, M.A. El BAKAli ${ }^{\mathrm{b}}$, F. GARCiA-Figueres $^{\mathrm{b}}$, C. CALVET $^{\mathrm{a}}$ \\ ${ }^{a}$ IRTA, Dept. Protecció Vegetal, Ctra. de Cabrils s/n, 08348 Cabrils, Barcelona, Spain \\ ${ }^{\mathrm{b}}$ Lab. Sanitat Vegetal, DARP, Generalitat de Catalunya, Via de Circulació Nord, Tram 6, Zona Franca, 08040 Barcelona, Spain
}

(Accepted 1 February 2007)

\begin{abstract}
High-impact chemical biocides are no longer used in crop production systems due to environmental concerns and sustainable agricultural practices must involve the use of environmentally friendlier alternatives for controlling pests and diseases. We compared the effect of two disinfestation treatments, solarization and metham sodium, combined with the arbuscular mycorrhizal fungus Glomus intraradices, the saprophytic fungus Trichoderma aureoviride and the plant growth-promoting rhizobacteria Bacillus subtilis, in strawberry crop production. Also, the effects of high temperatures achieved during the solarization process on the viability of mycorrhizal inocula were evaluated under controlled conditions in a laboratory study. Moist inocula of the arbuscular mycorrhizal fungus $G$. intraradices were maintained for three hours for five consecutive days at $35,40,45,50$ and $55^{\circ} \mathrm{C}$, respectively. Our results show that soil solarization and metham-sodium disinfestation improved strawberry yield by $24 \%$ and $18 \%$, respectively, compared with the fruit yield obtained in untreated soil, whereas application of T. aureoviride and B. subtilis did not affect plant production in the absence of a pathological agent. Solarization and metham-sodium application did not eliminate the natural populations of arbuscular mycorrhizal fungi and at the end of the experiment all plants, independently of the treatments, were mycorrhizal. After the heating treatments, under controlled conditions, the inoculum of $G$. intraradices submitted to $50{ }^{\circ} \mathrm{C}$ completely lost its mycorrhizal potential.
\end{abstract}

Glomus intraradices / mycorrhizae / Trichoderma / Bacillus / thermotolerance

\section{INTRODUCTION}

Soil-borne diseases cause heavy losses to most agricultural crops. Repeated planting of a crop in the same place results in the build-up of soil-borne pathogens. Chemical compounds have been used to control these pathogens; however, their excessive utilization has favoured the development of pathogens resistant to pesticides and recourse to broad spectrum biocides such as methyl bromide is no longer an option because of their hazardous environmental risks. The use of other alternatives, environmentally friendlier, including the use of biocontrol agents together with the development of suitable production practices, need to be studied in field situations (Katan, 1999).

Soil disinfestation is often a necessary step before planting strawberry (Fragaria vesca L.), as the continuous cropping in intensive and irrigated agriculture provides optimal conditions for the development of many soil-borne pathogens. Black root rot is a disease complex of strawberry that can reduce plant vigor and productivity; several pathogens, including Pythium and Rhizoctonia, are causal agents of this disease. Currently, management of strawberry root rot and other diseases relies exclusively on chemicals, particularly on fumigation with methyl bromide, which has become a standard practice in strawberry production because of its consistent and effective

* Corresponding author: amelia.camprubi@irta.es control of soil-borne pathogens and weed seeds (Locascio et al., 1999). The application of this biocide was a routine methodology even when pathological problems were not previously detected. However, under the Kyoto agreement, the use of methyl bromide has to be discontinued and the objective of this work was to assess the effect of a combination of treatments using biological control agents integrated with soil solarization and with metham sodium, a fumigant that is replacing methyl bromide in most strawberry production areas that is registered for all crops including food crops, and the final breakdown products include only carbon dioxide, water and small amounts of sodium and sulfur (Anderson and Haglund, 2002) .

Soil disinfestation carried out using heat, steam or hot water is an old practice used for controlling soil pests, and the use of solar energy to achieve an increase in the soil temperature has been shown to be effective at controlling some soil-borne diseases (DeVay and Katan, 1991; Gamliel et al., 2004; Luvisi et al., 2006). However, there has been little work done on the effect of solarization and high temperatures on the survival and colonizing ability of beneficial microbiota, especially arbuscular mycorrhizal fungi.

The role of arbuscular mycorrhizal fungi in improving plant growth in low-fertility soils and their effect in protecting crops against soil-borne plant pathogens has stimulated the interest in their potential use as biological agents for the control of plant pathogens (Barea et al., 2005). These fungi are obligate 
symbionts and can be found in most natural environments (Hepper, 1984). However, due to agronomical practices, the number and the diversity of these fungi decrease in agricultural soils.

The natural control of phytopathogens is based on the presence of suppressive soils where several biocontrol microorganisms are detected, such as Trichoderma and Bacillus (Montealegre et al., 2005). Species from the saprophytic fungi Trichoderma have been described as fungal biocontrol agents against a broad range of soil-borne diseases comprising Phytophtora, Pythium and Rhizoctonia root rots (Harman et al., 2004). The mechanisms associated with Trichoderma spp. disease control range from mycoparasitism, competition for nutrients and space to fungistasis and antibiosis, and can include the stimulation of plant defence mechanisms (Howell, 2003). A synergistic interaction between Trichoderma and some arbuscular mycorrhizal fungi on plant growth has been found to be related to the substrate used (Calvet et al., 1993).

Many rhizosphere-colonizing bacteria, including species of Bacillus, produce substances that stimulate plant growth or inhibit root pathogens (Glick, 1995). A broad-spectrum antibiosis to plant pathogens of some strains of Bacillus subtilis (Ehrenberg) Cohn has been described in vitro; this inhibition of deleterious root-colonizing microorganisms and their toxins has been suggested as the cause for better plant growth and disease control associated with soil inoculation with $B$. subtilis (Cook and Baker, 1983).

Here we studied the effect of high temperatures, achieved during soil solarization, on the viability of mycorrhizal inocula and we evaluated combinations of either solarization or metham-sodium application with the use of beneficial microorganisms on strawberry crop production. The microorganisms considered are the arbuscular mycorrhizal fungus Glomus intraradices Schenck and Smith, the saprophytic fungus Trichoderma aureoviride Rifai and the plant growth-promoting rhizobacteria (PGPR) B. subtilis.

\section{MATERIALS AND METHODS}

\subsection{Greenhouse experiment}

The study was conducted on a commercial strawberry farm cultivated with the same crop for over ten years located on the Mediterranean coastline, in the Northeast of Spain (Fig. 1). Three different disinfestation treatments were applied to soil plots $(5 \mathrm{~m} \times 10 \mathrm{~m})$ under plastic tunnels: (1) solarization, (2) metham sodium and (3) non-treated control. The solarized plot was flooded to its maximum water-holding capacity and then covered with a $30-\mu \mathrm{m}$ thick transparent polyethylene sheet for 7 weeks during the summer period. Soil temperatures were measured at the surface, and 10 and $20 \mathrm{~cm}$ deep and recorded every 30 minutes by a data logger. The system allowed the registering of the maximum temperatures achieved within the first layer of $20 \mathrm{~cm}$ of soil, where most of the arbuscular mycorrhizal fungal propagules can be found.

In order to estimate the number of infective arbuscular mycorrhizal fungal propagules present in the field, soil samples were collected before and after both soil solarization

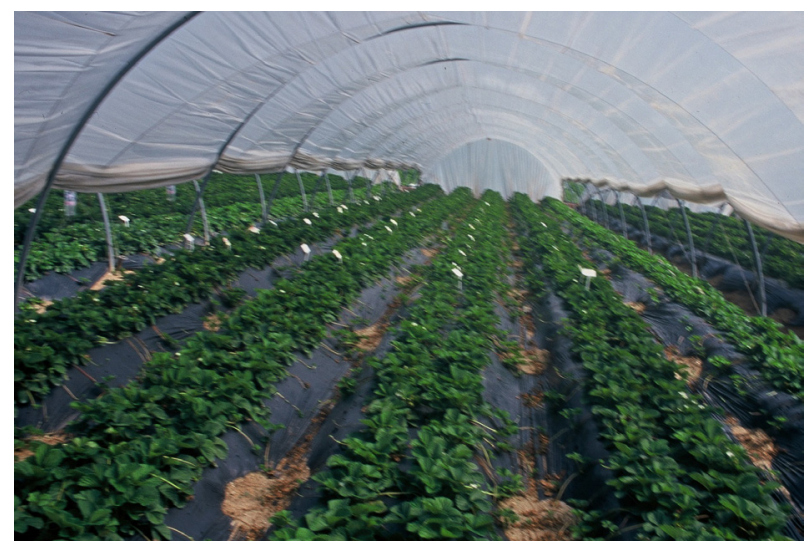

Figure 1. Strawberry cultivation under tunnels six months after the application of soil disinfestation treatments.

and metham-sodium application. The most probable number method (MPN) was used with tenfold series of soil dilutions with autoclaved sandy soil as a diluent (Porter, 1979; Powell, 1980).

After the disinfestation treatments, in each of the three main plots eight treatments of inoculation with beneficial microorganisms were established, replicated five times in a randomized design within each of the main plots. Each replicate consisted of ten strawberry plants. The microbial inoculation treatments were: (1) G. intraradices, (2) T. aureoviride, (3) B. subtilis, (4) G. intraradices plus T. aureoviride, (5) G. intraradices plus B. subtilis, (6) T. aureoviride plus B. subtilis, (7) G. intraradices plus T. aureoviride plus B. subtilis and (8) non-treated control. The strawberry cultivar used was "Pajaro". Plants were obtained as frozen runners from a growers' association (Frespol). The mycorrhizal fungus Glomus intraradices was isolated from a citrus orchard in Tarragona, Spain (Camprubí and Calvet, 1996) and registered in the International Bank for the Glomeromycota as BEG 72. The arbuscular mycorrhizal fungus was grown in leek (Allium porrum L.) pot cultures using autoclaved sandy soil as growing substrate and under greenhouse conditions. The inoculum used in the experiment was rhizosphere soil from the leek pot cultures containing more than 1000 spores per $10 \mathrm{~g}$ of soil. Spore numbers were recorded after wet sieving and decanting (Gerdemann and Nicolson, 1963) and extracting spores from the root in a blender. Twenty-five $g$ of soil inoculum located under the root system were applied per plant. The isolate of T. aureoviride used had been isolated from composted olive pumice (Calvet et al., 1989) and stored in silicagel tube cultures at $4{ }^{\circ} \mathrm{C}$. The saprophyte was first grown on potato dextrose agar (PDA, Difco @) and five $\mathrm{mL}$ of a suspension of $T$. aureoviride conidia in distilled water, adjusted to

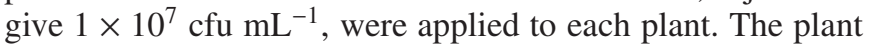
growth-promoting rhizobacteria treatment consisted of a mix of three strains of B. subtilis (T4, INR-7 and IN9376) supplied by the Department of Plant Pathology at Auburn University, Alabama, USA. The three strains were grown separately in tryptic soy agar for $48 \mathrm{~h}$, and cells were collected, washed and resuspended in sterile water to give a concentration of 
$1 \times 10^{8} \mathrm{cfu} \mathrm{mL}^{-1}$. The concentration was confirmed by spreading a decimally-diluted sample from each of the bottles used on tryptic soy agar plates. The inocula were applied by pouring $20 \mathrm{~mL}$ of the cell suspension onto the soil surface around the plant.

After eight months' growth and from the onset of production, every week for seven weeks, the fruit production was collected. The weight of fruits per plant was recorded as well as incidence of plant pathogens. To determine the cause of plant mortality the symptoms were evaluated and the fungi present in plant tissues were isolated. Field data were analyzed with a two-way analysis of variance. One factor was the disinfestation treatment (with three levels) and the second factor was the microorganism treatment (with eight levels). The resulting 24 combinations were replicated five times and each replicate consisted of ten plants. Significant differences between means were determined by Tukey's Multiple Range test $(P \leq 0.05)$.

\subsection{Isolation and identification of Rhizoctonia from dead plants}

To determine the cause of mortality of the strawberry plants, the roots and the stem bases were briefly washed with tap water, then immersed in water supplemented with $250 \mathrm{mg} \mathrm{mL} \mathrm{m}^{-1}$ chloramphenicol for 2 minutes and blotted dry with absorbent paper. Ten root segments were plated on potato dextrose agar media which contained $100 \mathrm{mg} \mathrm{L}^{-1}$ streptomycin sulphate. Plants were incubated at $25^{\circ} \mathrm{C}$ for 48 hours in the dark. Isolates were identified with a light microscope according to the morphological features of the mycelia (Parmeter and Whitney, 1970). Hyphal tips were transferred to potato dextrose agar and purified cultures were stored in soil wheatbran (Butler, 1980) and colonizing cereal grain (Sneh et al., 1991) for further studies.

\subsection{Effect of solarization temperatures on the viability of $G$. intraradices propagules}

In order to determine the effect of solarization temperatures on the survival of the arbuscular mycorrhizal fungus $G$. intraradices in the soil, a controlled experiment was carried out. Leek seedlings were inoculated with $G$. intraradices and grown in a sterile sandy soil. After nine months' growth, the leeks were cut, and the root system, colonized with $G$. intraradices, and the rhizosphere soil were blended until a homogenous substrate with a high density of arbuscular mycorrhizal propagules was obtained. This inoculum was divided into six batches, which were watered and covered with a transparent polyethylene sheet, and maintained for three hours for five consecutive days at $35,40,45,50$ and $55^{\circ} \mathrm{C}$, respectively. A control treatment at room temperature was added. Temperatures were selected to simulate the temperatures measured in the soil during the solarization process. The number of viable mycorrhizal propagules present in the inoculum after heating treatments was determined by the most probable number method using tenfold series of dilutions with autoclaved

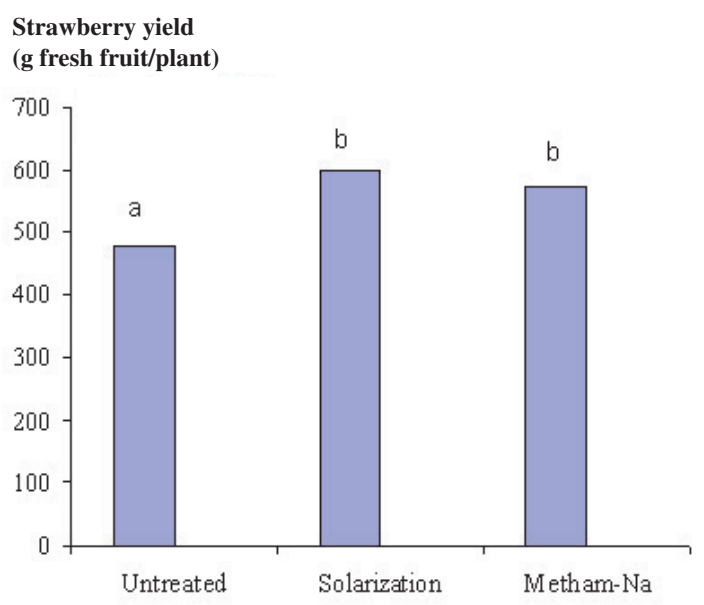

Figure 2. Effect of soil disinfestation on strawberry yield ( $\mathrm{g}$ of fresh fruit per plant) measured for seven weeks. Both soil disinfection treatments, solarization and metham-sodium application, significantly increased the production per plant when compared with the production recorded in the untreated soil. The same letter in the columns indicates that data do not differ according to Tukey's multiple range test $(P<0.05)$.

sandy soil as a diluent (Porter, 1979; Powell, 1980) and using leek seedlings as test plants.

\section{RESULTS AND DISCUSSION}

\subsection{Greenhouse experiment}

Soil solarization and metham-sodium disinfestation improved strawberry yield compared with the non-treated control (Fig. 2). Indeed, we found that fruit production increases of $18 \%$ and $24 \%$ were recorded in metham- $\mathrm{Na}$ and solarized treatments, respectively. No statistical differences were found between the two disinfestation treatments.

Solarization and metham-sodium application treatments both controlled the presence of Rhizoctonia sp. in the plants, whereas in non-treated plots $2 \%$ plant mortality was due to Rhizoctonia solani infection. Rhizoctonia solani was recovered consistently from the roots, crown and stem of symptomatic plants. The pathogenicity of the isolated strain was verified in a greenhouse experiment.

The number of arbuscular mycorrhizal propagules present in the soil after solarization and metham-sodium applications was equal (1.14 propagules/100 $\mathrm{mL}$ of soil) and lower than the value obtained for non-treated soil ( 4.5 propagules $/ 100 \mathrm{~mL}$ of soil). The application of solarization and metham sodium did not completely eliminate the natural populations of fungi, although the propagule densities of arbuscular mycorrhizal fungi in the soils were relatively low. At the end of the experiment, irrespective of the treatment applied, all plants, artificially inoculated with $G$. intraradices or not, had arbuscular mycorrhizal colonization in their roots. None of the beneficial microorganisms inoculated (G. intraradices, $T$. aureoviride and 
Table I. Strawberry yield (g of fresh fruit) per plant for seven weeks.

\begin{tabular}{llll}
\hline Treatment & No disinfestation & Solarization & Metham-Na \\
\hline Control & $515 \mathrm{a}$ & $602 \mathrm{a}$ & $603 \mathrm{ab}$ \\
G. intraradices (M) & $553 \mathrm{a}$ & $516 \mathrm{a}$ & $609 \mathrm{ab}$ \\
T. aureoviride (T) & $449 \mathrm{a}$ & $703 \mathrm{a}$ & $574 \mathrm{ab}$ \\
B. subtilis (PGPR) & $490 \mathrm{a}$ & $576 \mathrm{a}$ & $459 \mathrm{a}$ \\
$\mathrm{M}+\mathrm{T}$ & $479 \mathrm{a}$ & $618 \mathrm{a}$ & $619 \mathrm{~b}$ \\
$\mathrm{M}+\mathrm{PGPR}$ & $450 \mathrm{a}$ & $668 \mathrm{a}$ & $618 \mathrm{~b}$ \\
$\mathrm{~T}+\mathrm{PGPR}$ & $446 \mathrm{a}$ & $524 \mathrm{a}$ & $532 \mathrm{ab}$ \\
$\mathrm{M}+\mathrm{T}+$ PGPR & $447 \mathrm{a}$ & $580 \mathrm{a}$ & $570 \mathrm{ab}$ \\
\hline
\end{tabular}

Data are the means of five replications of ten plants. Means in a column followed by the same letter do not differ according to Tukey's multiple range test $(P<0.05)$.

Table II. Soil temperatures recorded every 30 minutes at the surface $(0 \mathrm{~cm})$, and $10 \mathrm{~cm}$ and $20 \mathrm{~cm}$ deep in the solarized field plot for seven weeks during the solarization period.

\begin{tabular}{cccccccc}
\hline Depth $(\mathrm{cm})$ & \multicolumn{3}{c}{ Soil temperature $\left({ }^{\circ} \mathrm{C}\right)$} & & \multicolumn{3}{c}{ Cumulative hours } \\
\cline { 2 - 5 } \cline { 6 - 8 } \cline { 6 - 8 } & Mean & Max. & Min. & & $40-44{ }^{\circ} \mathrm{C}$ & $45-49{ }^{\circ} \mathrm{C}$ & $>50{ }^{\circ} \mathrm{C}$ \\
\hline 0 & 35.2 & 55.8 & 20.4 & & 122 & 135 & 93 \\
10 & 34.6 & 44.1 & 24.2 & & 194 & 0 & 0 \\
20 & 33.7 & 40.7 & 25.0 & & 26 & 0 & 0 \\
\hline
\end{tabular}

B. subtilis) had a statistically significant effect on plant production in comparison with the non-inoculated plants (Tab. 1).

Pathogen control and nematode population density reductions have been found in soils following solarization (Katan, 1981). Although heat is the major killing agent, there is evidence that biological processes may contribute to effective control in terms of enhancement of antagonistic microorganisms and through a shift in the balance in favor of microorganisms which prevent reinfestation of pathogens (Katan, 1981). Along with the effects of the heating treatment on major soilborne plant pathogens, changes in population dynamics of a wide spectrum of soil bacteria and fungi have been reported in soils following heat treatments by solarization (Stapleton and DeVay, 1984). We found that the application of metham sodium or solarization in the soil eliminated Rhizoctonia disease incidence but did not eliminate the natural populations of arbuscular mycorrhizal fungi, as occurs after methyl bromide application (Menge et al., 1983).

The mechanisms of action of Trichoderma are known to be based on antibiosis, fungistasis and mycoparasitism (Vázquez et al., 2000). Recent studies indicated the importance of the induction of plant defence mechanisms for biocontrol (Barea et al., 2005). In our study, the application of $T$. aureoviride did not have an effect on the final production of strawberry, probably due to the irregular distribution and the low incidence of the pathogens across the strawberry plots. Vestberg et al. (2004) studied the effect of five beneficial microorganisms, including species of Glomus, Bacillus and Trichoderma, on the growth of micropropagated plants of strawberry and found that no single microorganism or mixture of microorganisms had a consistently positive effect on growth in the absence of a pathogen. Our results obtained with B. subtilis were similar to those obtained with $T$. aureoviride. According to Bai et al. (2003), some Bacillus strains probably promote plant growth through biocontrol of disease and insect pests. A potential effect on plant growth stimulation was not measured in our study because the results of the experiments were based on fruit yield.

This study did not provide results on the effect of arbuscular mycorrhizal fungus inoculation because all the plants were mycorrhizal at the end of the experiment, after eight months and seven weeks' growth in the soil under a plastic tunnel. Both the solarization and the metham-sodium treatment decreased the viable propagules by $75 \%$, but this low level of propagules was sufficient to colonize the roots of the highly mycotrophic strawberry plants across all treatments. The native fungi were as effective as the introduced $G$. intraradices and no differences were found, either in percentage or root colonization, in fruit yield.

\subsection{Effect of solarization temperatures on the viability of $G$. intraradices propagules}

During the solarization period, the soil temperature at the surface, under the plastic mulch layer, reached or exceeded $55{ }^{\circ} \mathrm{C}$ only for short periods, 30 minutes for five consecutive days. The maximum temperatures achieved at the $10 \mathrm{~cm}$ and $20 \mathrm{~cm}$ depths were $44.1^{\circ} \mathrm{C}$ and $40.7^{\circ} \mathrm{C}$, respectively (Tab. II). Temperature oscillations diminished with depth and therefore maximum and minimum values were maintained for longer periods. 
The number of propagules recovered from the moistened inoculum of $G$. intraradices stored at ambient temperature was 173 arbuscular mycorrhizal propagules/100 $\mathrm{mL}$ of soil. The same amount was recovered at $35^{\circ} \mathrm{C}$ and $40{ }^{\circ} \mathrm{C}$. These temperatures did not affect the viability of the moistened $G$. intraradices inoculum. When the temperature reached $45^{\circ} \mathrm{C}$, the viability of the inocula decreased to 11 arbuscular mycorrhizal propagules $/ 100 \mathrm{~mL}$ of soil, and temperatures of $50^{\circ} \mathrm{C}$ completely eliminated the viable propagules of the arbuscular mycorrhizal fungus.

Soil temperature is known to have a major influence on the establishment of arbuscular mycorrhizal fungi in plants. Temperatures from $25{ }^{\circ} \mathrm{C}$ to $30{ }^{\circ} \mathrm{C}$ were reported to be the optimum for the effectiveness of mycorrhiza. Sieverding (1988) found that arbuscular mycorrhizal fungi were more effective at $30^{\circ} \mathrm{C}$ than at $20^{\circ} \mathrm{C}$ of soil temperature. However, there are few studies on the effect of high temperatures on arbuscular mycorrhizal survival and root colonization. In our study, solarization, as well as metham-sodium application, reduced the number of arbuscular mycorrhizal propagules compared with non-treated soils but did not completely eliminate arbuscular mycorrhizal fungi propagules from the soil. Schreiner et al. (2001) suggested that solarization indirectly reduced arbuscular mycorrhizal fungi propagules by suppressing weeds that would maintain the fungi over the winter. Stapleton and DeVay (1984) studied the relationship between quantitative and qualitative alterations in microbial ecology induced by soil solarization, and did not find differences in the extent of internal root infections by arbuscular mycorrhizae in roots from solarized or untreated soils. Afek et al. (1991) found that soil solarization did not damage native arbuscular mycorrhizal fungi, whereas fumigation with methyl bromide did. BendavidVal et al. (1997) found that native populations were reduced to zero after 4 weeks of solarization treatment, whereas $G$. intraradices inoculum remained viable. Daft et al. (1987) found that spores of Glomus clarum Nicol. and Schenck were inactivated at $45^{\circ} \mathrm{C}$ and Menge et al. (1979) reported that the thermal death point of Glomus fasciculatum (Thaxter) Gerdeman \& Trappe was 10 minutes at $51.5^{\circ} \mathrm{C}$. It has also been shown that temperatures above $45{ }^{\circ} \mathrm{C}$ suppress ectomycorrhizal infectivity (Soulas et al., 1997). In our study, under controlled conditions, the propagules of the arbuscular mycorrhizal fungus $G$. intraradices totally lost their infectivity when the temperature applied was above $50{ }^{\circ} \mathrm{C}$. These high temperatures were recorded only in the soil surface during the solarization process. When the temperature applied was $45^{\circ} \mathrm{C}$ there was a decrease in the inoculum viability of $95 \%$; no effects were observed with applied temperatures of $40{ }^{\circ} \mathrm{C}$ and $35^{\circ} \mathrm{C}$. The accumulative hours above $40{ }^{\circ} \mathrm{C}$ but under $45^{\circ} \mathrm{C}$ achieved at $10 \mathrm{~cm}$ and $20 \mathrm{~cm}$ depths during the solarization process explained the $75 \%$ reduction in propagule infectivity observed in the solarized plot. This reduction allowed the establishment of arbuscular mycorrhizal colonization whilst effectively controlling $R$. solani.

Rhizoctonia solani is considered, like most soil pathogens, a mesophyllic fungus eradicated by the temperatures achieved in the solarization processes. Many beneficial microorganisms are thermotolerant and can be aggressive soil colonizers, in- cluding Bacillus sp., fluorescent Pseudomonas and Trichoderma. Therefore, our results indicate that, if no deficit in the effectivity of native arbuscular mycorrhizal fungi has been detected previously, solarization can be implemented without the need to re-introduce beneficial microbiota. In view of our results, G. intraradices is a thermotolerant soil fungus; in many published results native fungi can be reduced by solarization treatments but are seldom completely eliminated, allowing reestablishment of mycorrhizal colonization, as is the case in our study. Therefore, arbuscular mycorrhizal fungi should be considered as thermotolerant soil microbiota.

\section{CONCLUSION}

The disinfestation treatments, solarization and methamsodium application, resulted in an increase in fruit production of $24 \%$ and $18 \%$, respectively, compared with the nontreated control. We found that the application of T. aureoviride and $B$. subtilis did not have an effect on the final yield of strawberries, probably due to the low incidence of actual soilborne pathogens in the experimental area. The application of metham sodium or solarization did not eliminate the natural populations of arbuscular mycorrhizal fungi in the soil, as plants in uninoculated soil were mycorrhizal by the end of the experiment. Moreover, the native fungi were as effective as the introduced $G$. intraradices and no differences were found in fruit yield. Under controlled conditions, the propagules of the arbuscular mycorrhizal fungus $G$. intraradices totally lost their infectivity when the temperature applied was above $50{ }^{\circ} \mathrm{C}$. Temperatures above $45{ }^{\circ} \mathrm{C}$ were recorded during the solarization process only in the soil surface. These results confirm the feasibility of soil solarization as an alternative low-cost method to control diseases in adequate temperate climates, lacking deleterious effects on beneficial arbuscular mycorrhizal fungi. Therefore, our results indicate that, if no deficit in the effectivity of native arbuscular mycorrhizal fungi has been detected previously, solarization can be implemented without the need to re-introduce beneficial microbiota.

Acknowledgements: The authors thank Manel Tio from Frespol (Spain) for helping with the plastic tunnel experiments and Dr. J. Kloepper, Auburn University (USA), for supplying the strains of Bacillus subtilis. This work was supported financially by the "Ministerio de Educación y Ciencia".

\section{REFERENCES}

Afek U., Menge J.A., Johnson E.L.V. (1991) Interaction among mycorrhizae, soil solarization, metalaxyl and plants in the field, Plant Dis. $75,665-671$.

Anderson W.C., Haglund W.A. (2002) In-row sprayblade fumigation with metham sodium to control weeds and diseases, Washington State University, www.mtvernon.wsu.edu/methamsodium.html.

Barea J.M., Pozo J.M., Azcón R., Azcón-Aguilar C. (2005) Microbial co-operation in the rhizosphere, J. Exp. Bot. 56, 1761-1778.

Bai Y., Zhou X., Smith D.L. (2003) Enhanced soybean plant growth resulting from coinoculation of Bacillus strains with Bradyrhizobium japonicum, Crop Sci. 43, 1774-1781. 
BendavidVal R., Rabinowitch H.D., Katan J., Kapulnik Y. (1997) Viability of VA-mycorrhizal fungi following soil solarization and fumigation, Plant Soil 195, 185-193.

Butler E. (1980) A method for long time culture storage of Rhizoctonia solani, Phytopathology 70, 820-821.

Calvet C., Pera J., Barea J.M. (1989) Interactions of Trichoderma spp. with Glomus mosseae and two wilt pathogenic fungi, Agri. Ecosyst. Environ. 29, 59-65.

Calvet C., Pera J., Barea J.M. (1993) Growth response of marigold (Tagetes erecta L.) to inoculation with Glomus mosseae, Trichoderma aureoviride and Pythium ultimum in a peat-perlite mixture, Plant Soil 148, 1-6.

Camprubí A., Calvet C. (1996) Isolation and screening of mycorrhizal fungi from citrus nurseries and orchards and inoculation studies, HortScience 3, 366-369.

Cook R.J., Baker K.F. (1983) The Nature and practice of biological control of plant pathogens, The American Phytopathological Society, St. Paul, Minnesota 55121, USA.

Daft M.J., Spencer D., Thomas G.E. (1987) Infectivity of vesicular arbuscular mycorrhizal inocula after storage under various environmental conditions, T. Brit. Mycol. Soc. 88, 21-27.

DeVay J.E., Katan J. (1991) Mechanisms of pathogen control in solarized soils, in: Katan J., DeVay J.E. (Eds.), Soil Solarization, CRC Press, Boca Raton, Fl, pp. 87-101.

Gamliel A., Gadkar V., Zilberg V., Beniches M., Rabinowich E., Manor H., Wininger S., Kapulnik Y. (2004) Effect of solarization intensity on the control of pink root of chives, and the response of the crop to AM fungal application, Symbiosis 37, 233-247.

Gerdemann J.W., Nicolson T.H. (1963) Spores of mycorrhizal Endogone extracted from soil by wet sieving and decanting, T. Brit. Mycol. Soc. 46, 235-244.

Glick B.R. (1995) The enhancement of plant growth by free-living bacteria, Can. J. Microbiol. 41, 109-117.

Harman G.E., Howell C.R., Viterbo A., Chet I., Lorito M. (2004) Trichoderma species-opportunistic, avirulent plant symbionts, Nat. Rev. Microb. 2, 43-56.

Hepper C.M. (1984) Isolation and culture of VA mycorrhizal (VAM) fungi, in: Powell C.Ll., Bagyaraj D.J. (Eds.), VA Mycorrhiza, CRC Press, Boca Raton, Florida, USA, pp. 95-112.

Howell C.R. (2003) Mechanisms employed by Trichoderma species in the biological control of plant diseases: the history and evolution of current concepts, Plant Dis. 87, 4-10.

Katan J. (1981) Solar heating (solarization) of soil for control of soilborne pests, Ann. Rev. Phytopathol. 19, 211-236.

Katan J. (1999) The methyl bromide issue: problems and potential solutions, J. Plant Pathol. 81, 153-159.

Luvisi A., Materazzi A., Triolo E. (2006) Steam and exothermic reactions as alternative techniques to control soil-borne diseases in basil, Agron. Sustain. Dev. 26, 201-207.
Locascio S.J., Olson S.M., Chase C.A., Sinclair T.R., Dickson D.W., Mitchell D.J., Chellemi D.O. (1999) Strawberry production with alternatives to methyl bromide fumigation, Proc. Nat. Agr. Plastics Congress 28, 148-154.

Menge J.A., Johnson E.L.V., Minassian V. (1979) Effect of heat treatment and three pesticides upon the growth and reproduction of the mycorrhizal fungus Glomus fasciculatus, New Phytol. 82, 473-480.

Menge J.A., Raski D.J., Lider L.A., Johnson E.L.V., Jones N.O. (1983) Interactions between mycorrhizal fungi, soil fumigation and growth of grapes in California, Am. J. Enol. Viticult 34, 117-121.

Montealegre J.R., Herrera R., Velásquez J.C., Silva P., Besoaín X. (2005) Biocontrol of root and crown rot in tomatoes under greenhouse conditions using Trichoderma harzianum and Paenibacillus lentimorbus. Additional effect of solarization, Electron. J. Biotechnol. 8.

Parmeter J.R., Whitney H.S. (1970) Taxonomy and nomenclature of the imperfect state, in: Parmeter J.R. (Ed.), Rhizoctonia solani, biology and pathology, University of California Press, San Diego, pp. 7-19.

Porter W.M. (1979) The "most probable number" method for enumerating infective propagules of vesicular-arbuscular mycorrhizal fungi in soil, Aust. J. Soil Res. 17, 515-519.

Powell C.L. (1980) Mycorrhizal infectivity of eroded soils, Soil Biol. Biochem. 12, 247-250.

Schreiner R.P., Ivors K.L., Pinkerton J.N. (2001) Soil solarization reduces arbuscular mycorrhizal fungi as a consequence of weed suppression, Mycorrhiza 11, 273-277.

Sieverding E. (1988) Effect of soil temperature on performance of different VA mycorrhizal isolates with cassava, Angew. Botanik 62, 295-300.

Sneh B., Burpee L., Ogoshi A. (1991) Identification of Rhizoctonia species, APS Press, St. Paul, Minnesota.

Soulas M.L., Le Bihan B., Camporota P., Jarosz C., Salerno M.I., Perrin R. (1997) Solarization in a forest nursery: effect on ectomycorrhizal soil infectivity and soil receptiveness to inoculation with Laccaria bicolour, Mycorrhiza 7, 95-100.

Stapleton J.J., DeVay J.E. (1984) Thermal components of soil solarization as related to changes in soil and root microflora and increased plant growth response, Dis. Control Pest Manag. 74, 255-259.

Vázquez M.M., César S., Azcón R., Barea J.M. (2000) Interactions between arbuscular mycorrhizal fungi and other microbial inoculants (Azospirillum, Pseudomonas, Trichoderma) and their effects on microbial population and enzyme activities in the rhizosphere of maize plants, Appl. Soil Ecol. 15, 261-272.

Vestberg M., Kukkonen S., Saari K., Parikka P., Huttunen J., Tainio L., Devos N., Weekers F., Kevers C., Thonart P., Lemoine M.C., Cordier C., Alabouvette C., Gianinazzi S. (2004) Microbial inoculation for improving the growth and health of micropropagated strawberry, Appl. Soil Ecol. 27, 243-258. 